\title{
Decision to Purchase an Iphone Mobile Phones Which Influenced by Brand Images, Product Quality, and Price Perception (A Case Study on Students of Faculty of Economic, State University of Gorontalo, The Class of 2019)
}

\author{
Endi Rahman \\ Faculty of Economic, State University of Gorontalo, Gorontalo, Indonesia \\ Stanss L.H.V. Joyce Lapian \\ Faculty of Economic, Sam Ratulangi University, Manado, Indonesia \\ Agus Supandi Soegoto \\ Faculty of Economic, Sam Ratulangi University, Manado, Indonesia \\ Willem J.F.A Tumbuan \\ Faculty of Economic, Sam Ratulangi University, Manado, Indonesia
}

\begin{abstract}
This study aims to determine whether there is an influence of brand image, product quality, and price perception on purchase decision of iPhone mobile phones. This research was conducted at the Faculty of Economics Students, State University of Gorontalo, the class of 2019. The population in this study were students of the Faculty of Economics, State University of Gorontalo, the class of 2019, who had or were using an iPhone mobile phones. The sample is determined by the purposive sampling method with a total of 44 respondents. Data collection process has done by providing a list of questions/statements to respondents about brand image, product quality, and price perception, on purchasing decisions. This study uses multiple linear regression analysis tools. Hypotheses are tested by T-test and F-test. The test results show that brand image, product quality, both partially and simultaneously have a positive and significant effect on purchasing decisions, while price perceptions have a negative and insignificant effect on decision to buy iphone mobile phones by the students of Faculty Of Economic, State University of Gorontalo, the class of 2019
\end{abstract}

Keywords: Brand Image, Product Quality, Price Perception, Purchasing Decisions

DOI: $10.7176 / \mathrm{JMCR} / 75-01$

Publication date: January $31^{\text {st }} 2021$

\section{Introduction}

Telecommunications technology is one of the potential business opportunities utilized by producers in competition. Smartphone industry in Indonesia is currently experiencing a rapid increase. There are several smartphone brands that compete in Indonesia today in other markets Samsung, Apple, Oppo, Vivo, Xiaomi, Advan, Lenovo, and many more. The broader smartphone market has caused intense competition among business competitors in the telecommunications sector.

In the Indonesian market, there are many smartphone brands for sale, Apple is becoming one of the brands that is increasingly popular even though Apple's (iPhone) market share as one of the players in the upper class is also said to be declining, while three competing Android vendors, namely Samsung, Huawei, and Oppo actually recorded an increase.

(https://tekno.kompas.com/read/2019/11/28/16420057/pasaran-iphone-turun-ponsel-samsung-oppo-danhuawei-naik.Wahyunanda Kusuma Pertiwi 


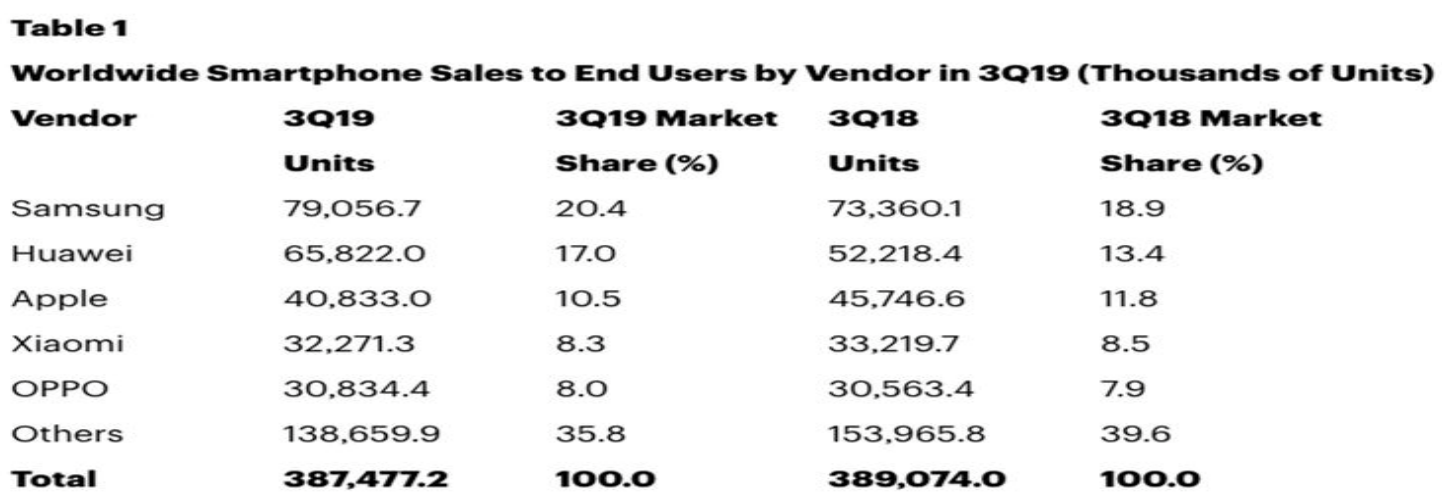

List of global smartphone market share in the third quarter of 2019 from the Gartner research institute (Gartner)

Samsung still dominates the global smartphone industry to 20.4 percent of market share, up around 2 percent from the same period last year. However, Huawei recorded the largest growth of 4 percent. In the third quarter of 2019, Huawei controlled the global smartphone market share by 17 percent so that it sat in second place after Samsung

Meanwhile, Apple in the third position has a market share decline of 1.3 percent, from 11.8 percent last year to 10.5 percent. iPhone shipments fell 10.7 percent from the range of 45 million units to 40 million units. From the table above shows a significant decline occurred in iPhone sales in Asia Pacific.

The decline in iPhone sales does not appear suddenly, but there are several reasons for the decline in sales because the price is expensive and not comparable with the facilities obtained, a faster iPhone release date makes the iPhone sales increase faster. On the other hand the decline in iphone sales will also come faster along with the emergence of competitors with better quality.

In addition to the above reasons, currently there are many refurbished iPhones on the market due to the large number of warranty claims received by Apple. Refurbished iPhones are used devices that result from warranty claims or software and hardware defects by users. The product was repaired, then retested thoroughly and remarketed by Apple at a cheaper price. However, consumers in Indonesia became to lack of confidence in the quality of refurbished products as evidenced by the petition signed by more than 200,000 consumers who refuse the existence of a refurbished iPhone.

Some iPhone users complained about existing iPhone facilities such as not being able to send data with other smartphones via Bluetooth, all content downloaded paid, and the absence of an external memory slot. Refurbished products made by the iPhone make many consumers become afraid to buy an iPhone. This happens because refurbished products were have been damaged so that consumers doubt the quality of it. (www.tabloidhape.com)

In the minds of consumers, price perception is an important consideration in buying a product because price is one of the determining factors in raising consumer buying decisions. The price of an iPhone may seem expensive compared to its competitors, but the iPhone works with a different operating system (iOS) so that the iPhone has more sophistication than its competitors, especially the Android operating system. However, there are many consumers who consider that iPhone are currently too expensive, ranging from $\$ 200$ for iphone 4 (initial product) to $\$ 1.715$ for iPhone 11 (newest product).

\section{Identification of problems}

There are some problems that identified in this study are: the declining sales of iPhone that affect sales of iPhone, The Brand Image of iPhone began to weak because iPhone is no longer an exclusive product, the emergence of refurbished iPhone makes people begin to doubt the quality of the iPhone on the market, the price of the iPhone is not comparable to owned quality and resulted in a decline in iPhone sales, the decline in iPhone purchasing may caused by the emergence of refurbished iphone.

\section{Formulation of the problem}

The formulation of the problem in this study are:

1. Does the brand image partially have a significant influence on iPhone purchasing decisions?

2. Does the product quality partially have a significant effect on purchasing decisions?

3. Does the price perception partially have a significant effect on purchasing decisions?

4. Does the brand image, product quality, and price perception simultaneously have a significant influence on purchasing decisions 


\section{Literature Review}

\section{Consumer Behavior}

Consumer behavior according to Swastha and Handoko (2000) as behavior that is shown by consumers in searching for, buying, using, evaluating and spending the products and services that they expect will satisfy their needs. Based on this opinion it can be concluded that consumer behavior is all psychological activities, actions and processes that drive such actions before buying, when buying, using products and services after doing the above mentioned things or evaluating activities.

There are two important elements of the meaning of consumer behavior, namely the process of decision making and physical activity, all of which involve individuals in assessing, obtaining and using goods and services economically. Individuals who make purchases to meet their personal needs or household consumption can be called end consumers. But that does not mean that other people are not involved in the buying process, however many people will be involved in making a decision to buy (Goenadhi, 2011)

\section{Buying Decision}

the definition of a purchasing decision is the stage in the decision making process where the consumer actually buys (Kotler, 2001). Decision making is an individual activity that is directly involved in obtaining and using the goods offered. The purchasing decision process can go through five stages of the purchasing process (Kotler, 2005), namely:

\section{A Purchasing Decisions Making Steps}

\begin{tabular}{|c|c|c|c|c|}
\hline $\begin{array}{l}\text { Recognize the } \\
\text { problem }\end{array}$ & $\begin{array}{l}\text { Search for } \\
\text { information }\end{array}$ & $\begin{array}{l}\text { Evaluation of } \\
\text { the } \\
\text { alternatives }\end{array}$ & $\begin{array}{l}\text { Buying } \\
\text { Decision }\end{array}$ & $\begin{array}{l}\text { Behavior } \\
\text { after buying } \\
\text { decision }\end{array}$ \\
\hline
\end{tabular}

Source : Kotler (2005)

1. The Problem Recognizion Stage

Is the first stage in a purchasing process, consumers begin to recognize the existence of a problem or need. The extent to which a product can meet customer expectations as long as consumers can also affect the introduction of needs and also customer satisfaction with the product. When a product can meet the needs of consumers, the actual and desired conditions will be aligned. But on the contrary, a product that does not meet the needs of consumers will result in actual circumstances that deviate from the desired state and this will trigger the introduction of needs, when repurchase is done by consumers.

2. Search for information

A consumer who is driven by his needs may also seek information about a product that will meet his needs and solve his problem.

Consumers can get information from many sources. Sources of consumer information include:

a. Personal sources (family, friends)

b. Commercial sources (advertising, sales force)

c. Public sources (electronic media, print media)

\section{Alternative evaluation}

Before making the purchase phase of a product, consumers also see other alternatives that can be used to meet their needs. Consumers will choose the attributes that will provide the benefits sought.

\section{Purchase decision stage}

The Consumer will determine choices and forms of purchase intentions after going through the previous stages, consumers will usually buy the product that best meets their needs. Consumers can also delay or avoid purchasing decisions if the risks faced are large when buying the product

\section{Behavior after purchase}

The consumer will evaluate the product he bought whether it is satisfactory or not, if it is satisfying and in accordance with consumer expectations, there is a possibility he will return to buy the product. (Kotler, 1996) states that purchasing decisions taken by a consumer are actually a collection of a number of decisions. Each purchase decision has a seven component structure which includes:

1. Decisions about the type of product

2. Decisions about the shape of the product

3. Decisions about brands 
4. Decisions about the number of products

5. Decisions about the time of purchase

6. Decisions about how to pay

7. Decisions about the time of purchase

8. Decisions about how to pay

\section{Brand Image}

Brand Image is the consumer's assessment of the brand in a market. Brand image is created based on personal experience or hearing the reputation of a brand from other people or the media. (Hoeffler and Keller, 2003). According to Hsieh et al (in Roslina: 2009), proposed three concepts to measure brand image namely; (1) functional benefits (functional benefits), which are designed to satisfy the needs of consumers in order to solve problems related to consumption. (2) symbolic benefits (symbolic benefits) are designed to meet consumer desires to enhance themselves (self-enhancement), role positions, membership in a group (group membership), or identification of the ego (ego indentification). (3) the benefits of experience (experiential benefit) which is designed to meet the desires of consumers relating to sensory pleasure (sensory pleasure), diversity (variety), and cognitive stimulation (cognitive stimulation).

\section{Brands and Perceptions}

According to Ferrinadewi (2008) Brand image is a perception of a brand that is a reflection of consumers' memory of their association with the brand. It can also be said that Brand Image is a concept created by consumers because of subjective reasons and personal emotions. Brand Image consists of components, namely brand association or favorability, strength \& uniqueness of brand association or positive attitude.

Positive attitude (favorability) and the uniqueness of brand associations consists of 3 things in the minds of consumers, namely the existence of desires, then the belief that certain brands can fulfill their desires and the most important is the consumer's belief that the brand has a significant difference compared to other brands. There are several aspects that make brand image so varied, namely:

1. where the location of the image / image means whether the image is in the minds of consumers or indeed on the object.

2. Its nature means whether the image refers to a process, form or a transaction.

3. The number means how many dimensions make up the image.

\section{Product Quality}

According to Kotler and Armstrong (2001), a product is anything that can be offered to the market to get attention, be bought, used, or consumed that can satisfy the desires or needs. Conceptually, the product is a subjective understanding of the manufacturer of something that can be offered as an effort to achieve organizational goals through meeting the needs and activities of consumers, in accordance with the competence and capacity of the organization and the purchasing power of the market. In addition, the product can also be defined as consumer perceptions described by producers through their production results.

According to David (1998) there are eight dimensions of product quality, namely:

\section{a) Performance}

Performance is the main characteristic or function of a product. This is the main benefit or efficacy of the products we buy. Usually this is our first consideration in buying a product.

b) Product Features

feature dimensions are additional characteristics or characteristics that complement the basic benefits of a product. Features are optional for consumers. When the main benefits have become standard, features are often added. features can improve product quality if competitors do not have them

c) Reliability

The reliability dimension is the opportunity for a product to be free from failures when carrying out its functions

d) Conformity with specifications (conformance to specification)

Conformance is the conformity of product performance with the stated standards of a product. This is a kind of "promise" that must be fulfilled by the product. Products that have the quality of these dimensions mean that they are in accordance with the standards.

e) Durability

Durability indicates to the age of the product, i.e. the amount of use of a product before the product is replaced or damaged. The longer the durability of course the more durable, durable products will be perceived as being of higher quality than products that are quickly used up or replaced quickly.

f) Can be improved (serviceability)

In accordance with its meaning, here the quality of the product is determined on the basis of its ability 
to be improved: easy, fast, and competent. Products that can be repaired are of course of higher quality compared to products that are not or difficult to repair if damaged.

g) Beauty (aestethic)

The beauty involves the appearance of products that can make consumers like. This is often done in the form of product design or packaging. Some brands are updated "face" to be more beautiful in the eyes of consumers.

h) Perceived quality

This is about concerns of the consumer's assessment of the image, brand, products of well-known branded products are usually perceived as being of higher quality compared to brands that are rarely or never heard of.

\section{Price Perception}

Price is the sum of all values given by customers to benefit from owning or using a product, both goods and services (Kotler, 2008). Consumers are different individuals with different needs. The ratings given for each product used by consumers are different from each other. Consumer perceptions of a price value varies so that a company must produce Perception has a great influence in every consumer's mind in assessing a product. (Prabowo, 2016). Price depends solely on company policy, but of course taking into account various things. The price is said to be expensive, cheap, or mediocre for each individual does not have to be the same, because it depends on the individual behind the environment and individual conditions. To be successful in marketing an item or service, every company must set prices accordingly. The pricing decision of a company is influenced by both the internal factors of the company and external environmental factors. (Omg and Sugiharto 2013).

\section{Conceptual Framework}

The framework of thought is a synthesis of a set of theories set out in a literature review, which is basically a systematic picture of the performance of a theory in providing solutions and alternative solutions to a set of problems. The variables in this study include brand image, product quality, price perception and purchasing decisions.

Figure 1

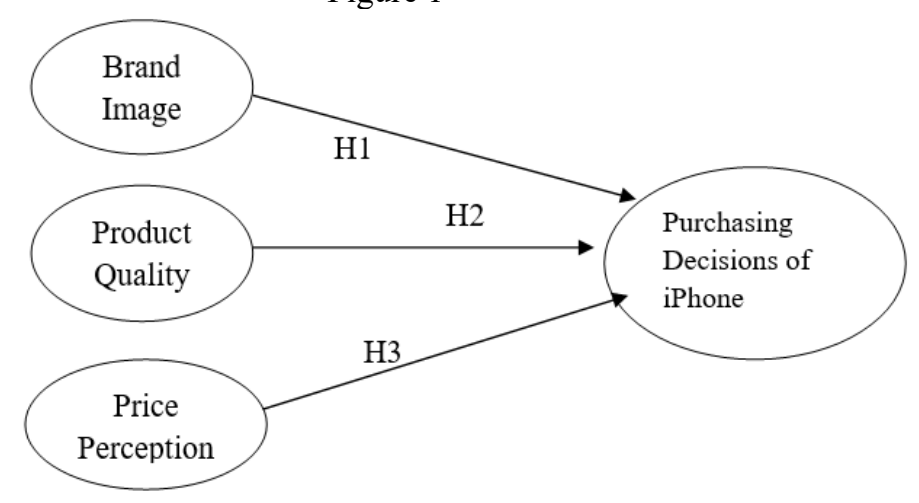

\section{Hypothesis}

Hypothesis is a statement about a concept that need to be tested for its truth (Siregar, 2016). So the hypothesis proposed by researcher is as follows:

Ha1: There is an Influence of Brand Image on Purchasing Decisions of iPhone Mobile Phones

Ha2: There is an Influence of Product Quality on Purchasing Decisions of iPhone Mobile Phones

Ha3: There is an Influnence of Price Perception on Purchasing Decisionsf of iPhone Mobile Phones Ha4: There is a Simoultaneously Influence of Brand Image, Product Quality, Price Perception on Purchasing Decisions of iPhone Mobile Phones

\section{Research methods \\ Population}

The population in this study were all tudents of the Faculty of Economics, State University of Gorontalo, class of 2019. A total of 440 people with a sample size of 44 . Samples were taken by means of purposive sampling, namely the sampling technique with certain considerations (Sugiyono, 2013). The intended consideration is the criteria determined by the researcher to determine the sampling, including the following criteria: a) Faculty of Economics students class of 2019. b) Aged 18 years and over. c) Students who have used or are using an iPhone mobile phones. 


\section{Sample}

The research subject in this study were 440 students, than obtained a research sample of $10 \%$ of the total population that met the criteria of 44 students as according to the opinion of Arikunto (2012). Data collection methods were used such as: observation, interviews and questionnaires. Data analysis techniques was using a descriptive analysis and multiple linear regression.

\section{Results and Discussion}

Validity test

Validity is a measure that shows the validity of a questionnaire. Validity test is done by bivariate analysis which is to see the correlation between each indicator with the total construct score. Done by comparing the value of $r$ count with $r$ table for degree offreedom $(\mathrm{df})=\mathrm{n}-2$, in this case the number of samples. The number of samples (n) in this study was 44 , so the magnitude of $\mathrm{df}$ is $44-2=42$, with a significance of $5 \%$ obtained $\mathrm{r}$ table $=0.297$. If the value of $r$ count is greater than $r$ table, it can be said that all indicator variables are valid. Conversely, if the calculated $r$ value is smaller than $r$ table, it can be said that the indicator variable is invalid. So it can determine whether or not a question is in each indicator variable.

1) Brand Image Validity

Validity test for Brand Image contains 7 statement items. The results of the correlation calculation for the score of each statement with the total score of the Brand Image variable (X1) can be seen in the following table Brand Image Validity Test $(X 1)$

\begin{tabular}{cccc}
\hline Statement Item & r count & r table & Result \\
\hline Item 1 & 0.301 & 0.297 & Valid \\
& & & \\
Item 2 & 0.498 & 0.297 & Valid \\
Item 3 & 0.591 & 0.297 & Valid \\
Item 4 & 0.606 & 0.297 & Valid \\
\hline Item 5 & 0.548 & 0.297 & Valid \\
Item 6 & 0.504 & 0.297 & Valid \\
Item 7 & 0.508 & 0.297 & Valid
\end{tabular}

Source: SPSS Processed Results, 2020

Validity of Product Quality

The validity test for Product Quality contains 12 statement items. The results of the correlation calculation for the score of each statement with the total score of the Product Quality variable (X2) can be seen in the following table: Validity of Product Quality Test Results Table (X2)

\begin{tabular}{cccc}
\hline Statement Item & r count & r table & Result \\
\hline Item 1 & 0.597 & 0.297 & Valid \\
Item 2 & 0.366 & 0.297 & Valid \\
Item 3 & & & \\
Item 4 & 0.456 & 0.297 & Valid \\
Item 5 & 0.335 & 0.297 & Valid \\
Item 6 & 0.597 & 0.297 & Valid \\
Item 7 & 0.597 & 0.297 & Valid \\
Item 8 & 0.597 & 0.297 & Valid \\
Item 9 & 0.597 & 0.297 & Valid \\
Item 10 & 0.633 & 0.297 & Valid \\
Item 1 & 0.647 & 0.297 & Valid \\
Item 12 & 0.620 & 0.297 & Valid \\
SPS Processed & 0.546 & 0.297 & Valid
\end{tabular}

Source: SPSS Processed Results, 2020

Validity of Price Perception

Validity test for Psychological Factors contains 4 statement items. The results of the correlation calculation for the score of each statement with the total score of the variable Price Perception (X3) can be seen in the following table: 


\begin{tabular}{cccc}
\multicolumn{5}{c}{ Validity of Price Perception Test Results Table (X3) } \\
\hline Statement Item & r count & r table & Result \\
\hline Item_1 & 0.550 & 0.297 & Valid \\
& 0.630 & 0.297 & Valid \\
Item_2 & & & Valid \\
Item_3 & 0.513 & 0.297 & Valid \\
Item_4 & 0.274 & 0.297 &
\end{tabular}

Source: SPSS Processed Results, 2020

Validity of Purchasing Decisions

The validity test for the Purchase Decision contains 11 statement items. The results of the correlation calculation for the score of each statement with the total score of the Purchase Decision variable (Y) can be seen in the following table:

Validity of Purchasing Decisions Test Results Table (Y)

\begin{tabular}{crcc}
\hline Statemeunt Item & r count & r table & Result \\
\hline Item 1 & 0.464 & 0.297 & Valid \\
Item 2 & 0.791 & 0.297 & Valid \\
Item 3 & 0.287 & 0.297 & Invalid \\
Item 4 & 0.791 & 0.297 & Valid \\
Item 5 & 0.464 & 0.297 & Valid \\
Item 6 & 0.791 & 0.297 & Valid \\
Item 7 & 0.642 & 0.297 & Valid \\
Item 8 & 0.664 & 0.297 & Valid \\
Item 9 & 0.791 & 0.297 & Valid \\
Item 10 & 0,287 & 0.297 & Invalid \\
Item 11 & 0,383 & 0.297 & Valid
\end{tabular}

Source: SPSS Processed Results, 2020

\section{Reliability Test}

Reliability test is used to measure how much the level of consistency of respondents to the questionnaire question items based on respondents' understanding of the questions in the questionnaire submitted. Reliability test was carried out using the Cronbach alpha method. Here are the results of calculating the reliability coefficient value for the research instrument.

\begin{tabular}{ccc}
\hline Variable & Croanbach's Alpha & Result \\
\hline Brand Image & 0,702 & Reliable \\
Product Quality & 0,679 & Reliable \\
Price Perception & 0,697 & Reliable \\
Purchasing Decisions & 0,623 & Reliable
\end{tabular}

Based on the reliability test results above, it can be said that all items are reliable. This can be seen from the whole statement item having Cronbach's alpha above the Cronbach's alpha standard value of 0.60 . So it can be concluded that all items measuring the variables of the questionnaire are reliable which means that the questionnaire which used in this study is a reliable questionnaire.

\section{Assumption Test}

a. Normality test

Normality Test is used to test whether a data is normal or not. Following are the results of the normality test of this study using the Kolmogorov-Smirnov One-Sample Test on SPSS 21 


\begin{tabular}{|c|c|c|}
\hline \multicolumn{3}{|c|}{$\begin{array}{l}\text { Normality Result Test Table } \\
\text { One-Sample Kolmogorov-Smirnov Test }\end{array}$} \\
\hline & & $\begin{array}{c}\text { Unstandardized } \\
\text { Residual }\end{array}$ \\
\hline $\mathrm{N}$ & Mean & $\begin{array}{r}44 \\
, 0000000\end{array}$ \\
\hline \multicolumn{3}{|l|}{ Normal Parameters $a, b$} \\
\hline & $\begin{array}{l}\text { Std. Deviation } \\
\text { Absolute }\end{array}$ & $\begin{array}{r}, / 5863934 \\
215\end{array}$ \\
\hline Most Extreme Differences & Positive &, 149 \\
\hline & Negative &,- 215 \\
\hline Kolmogorov-Smirnov Z & & 1,428 \\
\hline Asymp. Sig. (2-tailed) & &, 034 \\
\hline
\end{tabular}

a. Test distribution is Normal.

b. Calculated from data

Based on the table above, the Kolmogorov-Smirnov Test One-Sample test results in an asymptotic significance of $0.034 \geq 0.05$. Based on these results it can be concluded that the regression model has fulfilled the normality assumption.

b. Multicollinearity Test

Multicollinearity testing is used to show that among independent variables there is no strong correlation or multicollinearity problems occur. SPSS 21 analysis results shows the tolerance and VIF values of each variable can be seen in the following table.

Multcollinearity Result Test Table

\begin{tabular}{|c|c|c|c|}
\hline \multicolumn{4}{|c|}{ Coefficients $^{a}$} \\
\hline & \multirow[t]{2}{*}{ Model } & \multicolumn{2}{|c|}{ Collinearity Statistics } \\
\hline & & Tolerance & VIF \\
\hline \multirow{3}{*}{1} & Brand Image & ,869 & 1,151 \\
\hline & Product Quality &, 864 & 1,158 \\
\hline & Price Perception & ,957 & 1,045 \\
\hline
\end{tabular}

a. Dependent Variable: Purchasing Decisions

Based on table 11 it can be seen that the tolerance value of the product quality and price variables is more than 0.10 and the VIF is less than 10, it can be concluded that in the regression model, multicollinity does not occur.

\section{Multiple Regression Analysis}

This analysis is used to find out how an independent variables influence the dependent variable both simultaneously and partially.

\section{Coefficients ${ }^{\mathbf{a}}$}

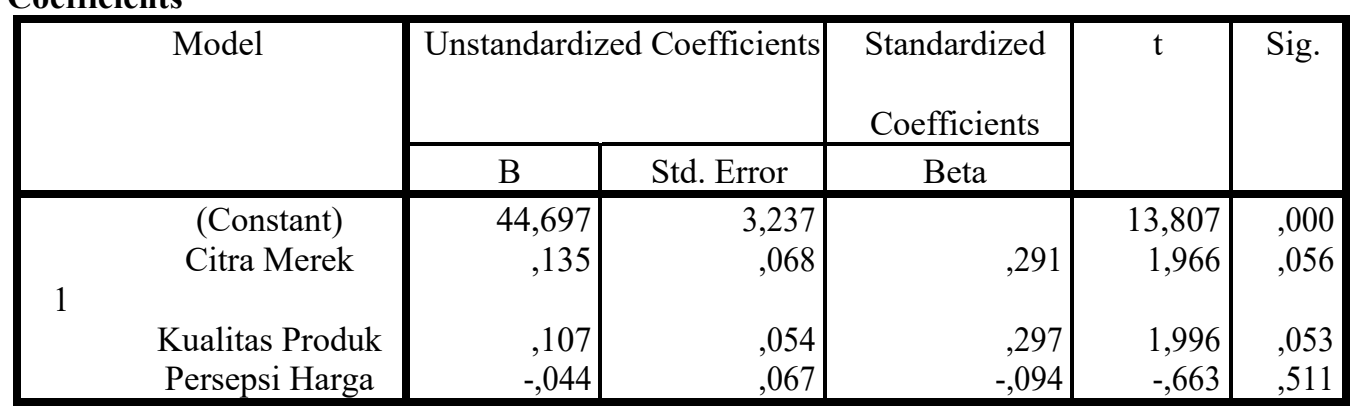

a. Dependent Variable: Purchasing Decisions

From the results of the regression analysis we can find the multiple regression equation as follows:

\section{$Y=44,697+0,135 X 1+0,107 X 2-0,044 X 3$}

Based on the above equation can be explained as follows:

a. The regression equation above explained that a constant value of 44,697 can be interpreted if the variable brand image, product quality, price perception are considered constant or have 
not changed, then the purchase decision will be 44,697.

b. Beta coefficient value on the brand image of 0.135 , meaning that the brand image (X1) increases, then the value of $\mathrm{Y}$ will also increase by 0.135 .

c. The beta coefficient value on product quality is 0.107 , meaning that the quality of the product (X2) increases, then the value of $\mathrm{Y}$ will also increase by 0.107 .

$\mathrm{d}$. The beta coefficient value on price perception (X3) is 0.044 and is negative, this shows that price perception has a opposite direction to the purchase decision. This implies that every increase in perception of the price of one unit, the purchase decision will decrease by 0.044 assuming that the other independent variables of the regression model are fixed.

F test

F test is performed to test whether there is a simultaneous influence on service quality and price on customer satisfaction. by the $\mathrm{F}$ test conducted, it can obtained the following results:

Tabel ANOVA ${ }^{\mathrm{a}}$

\begin{tabular}{|c|c|c|c|c|c|}
\hline Model & Sum of Squares & df & Mean Square & $\mathrm{F}$ & Sig. \\
\hline Regression & 7,684 & 3 & 2,561 & 4,140 & $012^{b}$ \\
\hline Residual & 24,748 & 40 & 619 & & \\
\hline Total & 32,432 & 43 & & & \\
\hline
\end{tabular}

a. Dependent Variable: Purchasing Decisions

b. Predictors: (Constant), Price Perception, Brand Image, Product Quality

From the table above, the Fcount is obtained, 4,140. Based on the table with a significance level $(\alpha)=5 \%$ or 0.05 , it is known that Ftable with $\mathrm{dfl}=\mathrm{k}-1=4-1=3$ and $\mathrm{df} 2=\mathrm{nk}=41$, then Ftable is 2, 83. Based on the calculation results obtained Fcount $(4,140)>$ Ftable (2.83). So it can be concluded that Price Perception, Brand Image, Product Quality simultaneously influence the Purchasing Decision.

T-test

T-test is conducted to see whether there is an effect of service quality and price on customer satisfaction, $\mathrm{t}$ test or commonly known as significant test of each regression coefficient to determine whether or not the influence of each independent variable on the dependent variable (Y). The t-test carried out obtained the following results:

\section{T-test Table}

\section{Coefficients $^{\mathrm{a}}$}

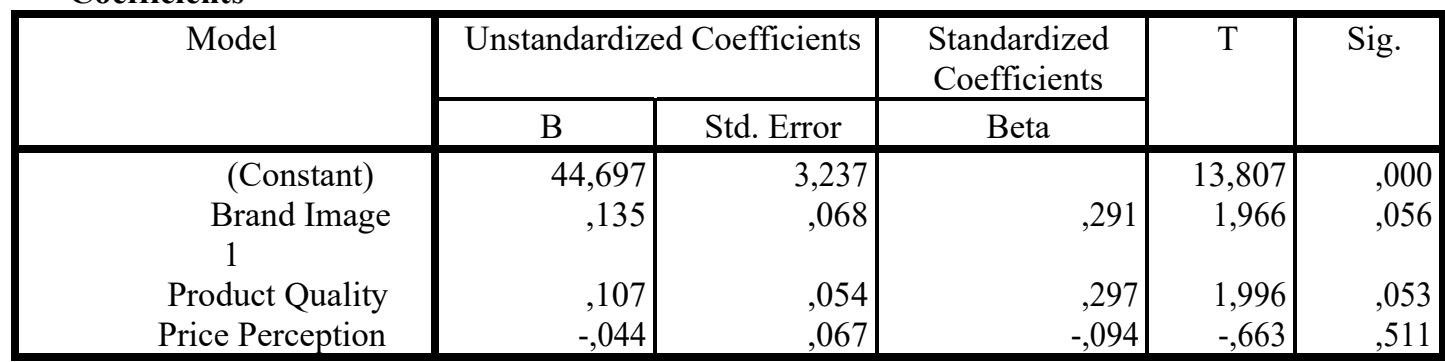

a. Dependent Variable: Purchasing Decision

The t-test was performed by comparing the t-counts in the above table with the t-values with a significance level of $5 \%$ or 0.005 and degrees of freedom $(\mathrm{df})=\mathrm{n}-\mathrm{k}=44-4=40$. Under these conditions a ttable1,683 was obtained. The results of the $t$ test are as follows:

a. Variable brand image (X1) with a regression coefficient of 0.135 indicates tcount $(\quad 1.966)>$ table (1.683) has a positive and significant influence.

b. Product quality variable (X2) with a regression coefficient of 0.107 indicates tcount (1.996) $>$ ttable (1.683) has a positive and significant influence.

c. Price perception variable (X3) with a regression coefficient of -0.044 indicates tcoun $(0.663)<$ table (1.683) has a negative and not significant influence.

Thus, the variable Brand Image, Product Quality partially influences purchasing decisions, but the Price Perception variable does not affect it. 


\section{Correlation Coefficient Test}

The correlation coefficient test is used to measure the correlation between variables. Correlation coefficient test results can be seen in the following table:

Correlation Coefficient Test Table

Model Summary

\begin{tabular}{|c|c|c|c|c|}
\hline Model & $\mathrm{R}$ & R Square & Adjusted R Square & $\begin{array}{ll}\text { Std. } & \begin{array}{l}\text { Error of the } \\
\text { Estimate }\end{array}\end{array}$ \\
\hline 1 & $487^{\mathrm{a}}$ & ,237 &, 180 &, 787 \\
\hline
\end{tabular}

a. Predictors: (Constant), Price Perception, Brand Image, Product Quality

From the table above it can be seen that the correlation coefficient between variables is 0.487 which indicates that the relationship between variables is strong.

\section{Determination Coefficient Test}

The coefficient of determination $\left(\mathrm{R}^{2}\right)$ essentially measures how far the model's ability to explain the variation of the dependent variable.

Determinant Coefficient Test Table

Model Summary

\begin{tabular}{|c|r|r|r|rr|}
\hline Model & \multicolumn{1}{|c|}{$\mathrm{R}$} & \multicolumn{1}{|c|}{ R Square } & Adjusted R Square & \begin{tabular}{l} 
Std. $\begin{array}{l}\text { Error of the } \\
\text { Estimate }\end{array}$ \\
\hline 1
\end{tabular} \\
\hline
\end{tabular}

a. Predictors: (Constant), Price Perception , Brand Image, Product Quality

From table above, a coefficient of determination is 0.237 or $24 \%$ obtained. This means that the magnitude of the influence of the variable Price Perception, Brand Image, Product Quality to variations in purchasing decisions changes by $24 \%$ while $76 \%$ is influenced by other variables which not examined in this study.

\section{The Influence of Brand Image on Purchasing Decisions}

The results of this study indicate that there is a partially positive and significant influence of brand image on iphone purchasing decisions based on the partial test results (t-count) the influence of brand image on purchase decisions obtained regression coefficients 0.135 and $t$-count $(1.966)>t$ - table (1.683). This because some of the first factors lifestyle habits among students tend to be excessive so students usually shop for branded goods, they feel proud and classy when using an iPhone. Second, iPhone is a trusted brand. So it can be concluded that brand image has a positive and significant effect on iPhone purchasing decisions on Faculty of Economics students, State University Of Gorontalo, The Class of 2019

\section{The Influence of Product Quality on Purchasing Decisions}

The results of this study indicate that there is a partially positive and significant influence on product quality on Iphone purchasing decisions. Based on the partial test results ( $\mathrm{t}$-count) the influence of product quality on purchasing decisions Product quality variable (X2) with a regression coefficient of 0.107 indicates tcount (1.996)> t-table (1.683) has a positive and significant effect. This shows that the product quality has influences the iPhone purchasing decisions on the Faculty of Economics students. This because some of the first things some students buy iPhone because of its application inside was very entertained. Second, the iPhone has a strong and durable endurance, and third, the iPhone has an excellent performances. So it can be concluded that product quality has a positive and significant effect on iPhone purchasing decisions, $s$ the second hypothesis is proven. This shows that the product quality has influence the iPhone purchasing decisions on the Faculty of Economics students, The, State University Of Gorontalo, The Class of 2019.

\section{The Influence of Price Perception on Purchasing Decisions}

The results of this study indicate that there is no effect of price perception partially on iPhone purchasing decisions on The Faculty of Economics students. Price perception variable (X3) with a regression coefficient of - 0.044 shows $\mathrm{t}$-count $(0.663)>\mathrm{t}$-table $(1.683)$ has influence purchasing decisions negatively and not significant. This because some students thought that the brand will provides added value for them, because of their perceptions make that students become interested in buying it, so they will be willing to buy / pay dearly to get the goods they want and there is an assumption that the more expensive an item then the quality of the goods is getting better so that most students buy an item without seeing the price but only consider the quality that will be obtained.

4. The Influence of Brand Image, Product Quality, and Price Perception on Purchasing Decisions Based on the results of the simultaneous test calculations obtained Fcount (4.140)> Ftable (2.83). So it can be concluded Price Perception, Brand Image, and Product Quality simultaneously influence the Purchasing Decision of iPhone. When compared with the expected significance level of $5 \%$, the significance of the F-count is smaller than the expected significant level $(0 \%<5 \%)$. Thus the brand image, product quality, simultaneously has a positive 
and significant influence on purchasing decisions while price perception has a negative influence on purchasing decisions of iPhone

\section{CONCLUSIONS}

Based on the research results of the Influence of Brand Image, Product Quality, and Price Perception on Purchasing Decisions on iPhone Mobile Phones (A Case Study on The Faculty of Economics Students, The Class of 2019, State University of Gorontalo), the conclusions can be obtained as follows:

1. Brand Image has a positive and significant influence on the Purchasing Decision of iPhone Mobile Phones on The Faculty of Economics Students, State University Of Gorontalo, The Class of 2019

2. Product Quality has a positive and significant influence on the Purchasing Decisions of Iphone Mobile Phones on the Faculty of Economics students, The Class of 2019, State University Of Gorontalo

3. Price Perception has a negative or insignificant influence on the Purchasing Decision of Iphone Mobile Phones on on the Faculty of Economics students, The Class of 2019, State University Of Gorontalo.

4. Brand Image, Product Quality, and Price Perception have a significant influence on purchasing decisions of iPhone Mobile Phone on the Faculty of Economics students, State University Of Gorontalo, The Class of 2019

\section{REFERENCES}

Arikunto, S. 2002. Metodologi Penelitian Suatu Pendekatan Proposal. Jakarta: PT. Rineka Cipta. (2012). Prosedur Penelitian Suatu Pendekatan Praktek. Jakarta: Rineka Cipta

David, A Garvin. (1998). Managing Quality. New York: Free Press

Fandy Tjiptono. 1997. Strategi Bisnis Pemasaran. Yogyakarta: Andi

Ferrinadewi, Erna. 2008. Merek dan psikologi konsumen. Yogyakarta Graha Ilmu.

Ghozali, Imam. 2011. “Aplikasi Analisis Multivariate Dengan Program SPSS”.

Semarang: Badan Penerbit Universitas Diponegoro.

Handoko T. Hani, 2002, Manajemen Personalia dan Sumberdaya Manusia, Edisi II, Cetakan Keempat Belas, Penerbit BPFE, Yogyakarta.

Hoeffler, Steve., Keller, Kevin Lane. (2003). The Marketing Advantages of Strong Brands, Brand Management, Vol. 10, No.6

Kotler, Philip. 2001. Manajemen Pemasaran: Analisis, Perencanaan, Implementasi dan Kontrol. Jakarta: PT. Prehallindo.

Kotler, Philip. 2005. Manajamen Pemasaran, Jilid 1 dan 2. Jakarta: PT. Indeks Kelompok Gramedia.

Kotler ,Philip dan Kevin L. Keller. 2006. Manajemen Pemasaran edisi ke 12 Jilid ke 1. New Jersey, Indeks.

Kotler, Amstrong. 2008. Dasar-dasar Pemasaran. Edisi Bahasa Indonesia.

Jakarta : PT. Prehallindo.

Kotler, Philip dan Kevin Lane Keller. (2007). Manajemen Pemasaran. Jakarta: PT Indeks.

Omg Ian Antonius dan Sugiharto Sugino (2013).Analisa Pengaruh Strategi Diferensiasi, Citra Merek, Kualitas Produk dan Harga terhadap Keputusan Pembelian Pelanggan di Cincau Station Surabaya. Vol 1 No 2

Prabowo,Indra Jaya Krisna Gede. 2016. Pengaruh Citra Merek, Kualitas Produk, Persepsi Harga Dan Word Of Mouth Terhadap Minat Beli Iphone. Vol 2 No 6

Sugiyono, 2013, Metode Penelitian Kuantitatif, Kualitatif dan $R \& D$, Bandung : Alfabeta

Swastha, Basu dan Handoko, 2000, Manajemen Pemasaran (Analisa Perilaku Konsumen), Yogyakarta : BPFE UGM.

https://tekno.kompas.com/read/2019/11/28/16420057/pasaran-phone-turun-ponsel-samsung-oppo-dan-huaweinaik. WahyunandaKusumaPertiwi accessed April 25, 2020

https://makemac.grid.id/ accessed April 25, 2020

https://tabloidhp.net/id accessed April 25, 2020 